\title{
Comparison of Grass and Legume Silages for Milk Production. 1. Production Responses with Different Levels of Concentrate
}

\author{
R. J. Dewhurst, ${ }^{\star}$ W. J. Fisher,† J. K. S. Tweed, ${ }^{\star}$ and R. J. Wilkinsł \\ Institute of Grassland and Environmental Research \\ *Plas Gogerddan, Aberystwyth SY23 3EB, U.K. \\ †Trawsgoed Research Farm, Aberystwyth SY23 4LL, U.K. \\ ¥North Wyke Research Station, Okehampton EX20 8SB, U.K.
}

\begin{abstract}
Silages prepared from pure stands of ryegrass, alfalfa, white clover, and red clover over two successive year were offered to lactating dairy cows in two feeding experiments. Proportional mixtures of all cuts prepared in a yr were used to ensure that the forage treatments were representative of the crop. Additional treatments involved mixtures of grass silage with either white clover silage or red clover silage (50/50, on a DM basis). Silages were prepared in round bales, using a biological inoculant additive, and wilting for up to $48 \mathrm{~h}$. Although the legumes were less suited to silage-making than grass, because of their higher buffering capacity and lower water-soluble carbohydrate content, all silages were well-fermented. A standard concentrate was offered at a flat-rate $(8 \mathrm{~kg} / \mathrm{d}$ in yr 1 , and 4 or $8 \mathrm{~kg} / \mathrm{d}$ in yr 2). All of the legume silages led to higher DM intake and milk yields than for the grass silage, with little effect on milk composition. Intake and production responses to legumes were similar at the two levels of concentrate feeding and with forage mixtures they were intermediate to those for the separate forages. An additional benefit of the clover silages, particularly red clover silage, was the increase in levels of polyunsaturated fatty acids, particularly $\alpha$-linolenic acid, in milk. Legume silages also led to a lower palmitic acid percentage in milk. The efficiency of conversion of feed $\mathrm{N}$ into milk $\mathrm{N}$ declined with increasing levels of legume silage. White clover silage led to a higher $\mathrm{N}$-use efficiency when the effect of $\mathrm{N}$ intake level is taken into account.
\end{abstract}

(Key words: silage, clover, alfalfa, milk production, fatty acid)

Abbreviation key: $\mathbf{A}=$ alfalfa silage, $\mathbf{F A M E}=$ fatty acid methyl esters, $\mathbf{G}=$ grass silage, $\mathbf{G 4}=\mathrm{G}$ with $4 \mathrm{~kg} /$ d concentrates, $\mathbf{G 8}=\mathrm{G}$ with $8 \mathrm{~kg} / \mathrm{d}$ concentrates, GRC = mixture of $\mathrm{G}$ and RC, GRC4 = GRC with $4 \mathrm{~kg} / \mathrm{d}$

Received November 28, 2002.

Accepted April 1, 2003.

Corresponding author: R. J. Dewhurst; e-mail: Richard.Dewhurst @bbsrc.ac.uk. concentrates, GRC8 = GRC with $8 \mathrm{~kg} / \mathrm{d}$ concentrates, $\mathbf{G W C}=$ mixture of $\mathrm{G}$ and $\mathrm{WC}, \mathbf{R C}=$ red clover silage, $\mathbf{R C 4}=\mathrm{RC}$ with $4 \mathrm{~kg} / \mathrm{d}$ concentrates, $\mathbf{R C 8}=\mathrm{RC}$ with 8 $\mathrm{kg} / \mathrm{d}$ concentrates, $\mathbf{R I C}=$ roughage intake control, $\mathbf{W C}=$ white clover silage, $\mathbf{W C 8}=\mathrm{WC}$ with $8 \mathrm{~kg} / \mathrm{d}$ concentrates.

\section{INTRODUCTION}

Earlier experiments have established the high intake and milk production potential of legume silages. Castle et al. (1983) and Auldist et al. (1999) showed the high feeding value of white clover silage for dairy cows. Other studies (e.g., Thomas et al., 1985 with red clover and Hoffman et al., 1998 with alfalfa) have demonstrated the superiority of legume silages in comparison with grass silages. However, the area of forage legumes has been declining for a number of reasons, including the relatively low cost of $\mathrm{N}$ fertilizer, and difficulties with the agronomy and ensiling of legumes.

Further work on legume silages is timely because of growing interest in organic and low-input production systems as we become increasingly aware of the pollution potential from dairy units (Jarvis et al., 1996). Plant breeding has improved the persistency and disease resistance of legumes (Rhodes and Ortega, 1997). Earlier work often used long periods of wilting, precision-chop harvesting and high levels of formic acid and/ or formalin as additives. The loss of high-protein leaf material is a particular problem with legumes and is exacerbated by extensive handling of the crop. In this work we have adopted shorter periods of wilting (up to $48 \mathrm{~h}$ ), baling of silage with minimal handling and chopping, and the use of a biological inoculant silage additive to reduce harvesting losses and avoid the safety and equipment corrosion problems associated with acids. There is limited earlier evidence, with beef cattle, of successful feeding of red clover silages prepared with wilting, but without the use of chemical additives (Thomas et al., 1981).

The objective of this work was to evaluate feed intake and milk production with diets based on legume silages prepared using new technologies of biological inocu- 
lants and big bales. A further objective was to investigate effects on $\mathrm{N}$ utilization and the fatty acid composition of milk fat.

\section{MATERIALS AND METHODS}

\section{Field Management}

Pure stands of forage crops were established for this work during the summer and fall of 1997: red clover (Trifolium pratense cv. Milvus), white clover (Trifolium repens $\mathrm{cv}$. Aran), alfalfa (Medicago sativa cv. Vertus) and ryegrass (mixture of Lolium perenne cv. AberElan, Lolium $\times$ boucheanum cv. AberComo and Lolium multiflorum cv. Augusta). The forages were grown at Aberystwyth $\left(52^{\circ} 25^{\prime} \mathrm{N}, 4^{\circ} 05^{\prime} \mathrm{W}\right)$ and harvested over the following two growing seasons (1998 and 1999).

The legume crops received $85 \mathrm{~kg}$ phosphate/ha (as triple superphosphate) and 260 (185 for white clover) $\mathrm{kg}$ potash/ha (as muriate of potash) in March of each year. Additional applications were given in mid-season (56 kg potash/ha in 1998; $115 \mathrm{~kg}$ phosphate/ha and 150 $\mathrm{kg}$ potash/ha in 1999). The ryegrass crop received 320, 47 , and $47 \mathrm{~kg} / \mathrm{ha}$ of $\mathrm{N}$, phosphate, and potash in 1998 and 335, 50, and $50 \mathrm{~kg} / \mathrm{ha}$ in 1999.

\section{Silage-making}

The timing of silage cuts was planned to be optimal for the growth patterns of individual crops, modified according to weather conditions. Cutting dates, approximate growth stages, and the percentage contribution of each cut to annual production for each crop is given in Table 1. Experiences in 1998 suggested that the potential of ryegrass and red clover might further be exploited by cutting these crops on 4 occasions. However, poor ground conditions meant that we were unable to conserve the small fourth growth of red clover.

Crops were mowed using a disc mower fitted with rubber rollers. Wilting guidelines were that crops should be baled once they reached a DM content of 30 to $35 \%$ or, in any event, within $48 \mathrm{~h}$ of cutting. The crops were wilted in the mower swaths for most of the wilting time and tedded into rows 2 to $3 \mathrm{~h}$ before baling. Crops were baled using a round baler, with chopping used only for the ryegrasses. An inoculant additive designed to supply 1 million cfu of Lactobacillus plantarum strain MTD1 per g of forage (Ecosyl; Ecosyl Products Ltd., Stokesley, UK) was applied to all crops, during baling, at the recommended rate of $1.5 \mathrm{~L} / \mathrm{t}$ of crop. On the basis of the good fermentations obtained in 1998, we were prepared to use slightly wetter material at ensiling during 1999.

\section{Feeds}

A recurrent difficulty of this type of work has been the need to identify representative material. Consequently, in this work we used all material produced from the fields over the yr in each feeding experiment (see Table 1). Although there were some differences in treatments and objectives between the $2 \mathrm{yr}$, we maintained several common treatments in order to provide yr replication. Mixtures of silages prepared from each crop over each growing season were used in the feeding experiments in order to ensure that feeds were more representative of the crop type. Bales were chopped and mixed just prior to feeding.

A standard concentrate was used for both years of the experiment, comprising (\%): wheat (30.0), palm kernel expeller (15.0), corn gluten feed (14.0), extracted rapeseed meal (double-zero) (11.0), extracted sunflower meal (9.0), molasses (5.0), expeller linseed meal (5.0), groundnut meal (5.0), extracted soybean meal (2.0), vegetable fat (1.5), and minerals/vitamins (2.5). The mineral/vitamin premix supplied (on a concentrate DM basis): $11,600 \mathrm{IU}$ of vitamin $\mathrm{A} / \mathrm{kg}, 2300 \mathrm{IU}$ of vitamin $\mathrm{D}_{3} / \mathrm{kg}, 29 \mathrm{IU}$ of vitamin $\mathrm{E} / \mathrm{kg}, 35 \mathrm{mg} / \mathrm{kg}$ of $\mathrm{Cu}, 140 \mathrm{mg} /$ $\mathrm{kg}$ of $\mathrm{Mn}, 0.46 \mathrm{mg} / \mathrm{kg}$ of Se and $14 \mathrm{mg} / \mathrm{kg}$ of $\mathrm{Zn}$.

\section{Animal Measurements}

Experiment 1 (silages prepared in 1998). The first experiment involved 18 Holstein-Friesian cows (mean $\mathrm{BW}=579(40.4) \mathrm{kg}$; mean initial DIM $=64(\mathrm{SD}=22.3)$, in a 3-period cyclical changeover-design experiment (Davis and Hall, 1969), with 4-wk periods. One block of cows $(n=6)$ had previously been prepared with simple rumen and duodenal cannulae and additional measurements are reported by Dewhurst et al. (2003).

There were 6 dietary treatments based on 6 different forages: grass silage $(\mathbf{G})$, red clover silage $(\mathbf{R C})$, white clover silage (WC), alfalfa silage (A), and 50/50, (DM basis) mixture of $\mathrm{G}$ and RC (GRC) and $\mathrm{G}$ and $\mathrm{WC}$ (GWC). The cows had ad libitum access to the forages either through roughage intake control (RIC) feeders (Insentec B.V., Marknesse, The Netherlands) in a freestall barn, or through individual stalls (for the fistulated cows). All cows were given $8 \mathrm{~kg} / \mathrm{d}$ of the same concentrate, with $3 \mathrm{~kg}$ offered at each milking and 2 $\mathrm{kg}$ distributed as a mid-day feed (fistulated cows) or through out-of-parlor feeders. The concentrate was designed to balance the protein content of $\mathrm{G}$ and so provided excess protein in other diets.

Cows were milked two times each day, at approximately 0600 to $0700 \mathrm{~h}$ and 1600 to $1700 \mathrm{~h}$. Feed intake and milk yields were recorded daily throughout the experiment; milk composition was recorded from 4 consecutive milkings each wk. The model of Tolkamp et 
Table 1. Details of the silages prepared during 1998 and 1999.

\begin{tabular}{|c|c|c|c|c|c|}
\hline Year & Crop & Cut & $\begin{array}{l}\text { Cutting } \\
\text { date }\end{array}$ & $\begin{array}{l}\text { Growth } \\
\text { stage }\end{array}$ & $\begin{array}{l}\% \text { of annual } \\
\text { mixture } \\
\text { (DM basis) }\end{array}$ \\
\hline \multirow[t]{12}{*}{1998} & \multirow[t]{3}{*}{ Grass } & 1 & 16 May & Pre-flowering & 42.4 \\
\hline & & 2 & 2 July & Mid-flowering & 33.2 \\
\hline & & 3 & 10 August & Early flowering & 24.4 \\
\hline & \multirow[t]{3}{*}{ Red clover } & 1 & 17 May & Mid-flowering & 42.7 \\
\hline & & 2 & 23 July & Late flowering & 32.8 \\
\hline & & 3 & 19 September & Early flowering & 24.5 \\
\hline & \multirow{3}{*}{ White clover } & 1 & 10 June & Late flowering & 43.4 \\
\hline & & 2 & 6 August & Early flowering & 29.1 \\
\hline & & 3 & 20 September & Late bud & 27.5 \\
\hline & \multirow[t]{3}{*}{ Alfalfa } & 1 & 17 May & Bud & 39.2 \\
\hline & & 2 & 23 July & Mid-flowering & 37.6 \\
\hline & & 3 & 19 September & Bud & 23.2 \\
\hline \multirow[t]{10}{*}{1999} & \multirow{4}{*}{ Grass } & 1 & 27 May & Mid-flowering & 32.6 \\
\hline & & 2 & 6 July & Mid-flowering & 28.8 \\
\hline & & 3 & 20 August & Mid-flowering & 24.4 \\
\hline & & 4 & 11 October & Pre-flowering & 14.2 \\
\hline & \multirow[t]{3}{*}{ Red clover } & 1 & 17 May & Early bud & 33.1 \\
\hline & & 2 & 6 July & Early flowering & 40.8 \\
\hline & & 3 & 22 August & Early flowering & 26.1 \\
\hline & \multirow{3}{*}{ White clover } & 1 & 8 June & Early flowering & 46.4 \\
\hline & & 2 & 26 July & Flowering & 44.3 \\
\hline & & 3 & 11 October & Early flowering & 9.3 \\
\hline
\end{tabular}

al. (1998) was used to estimate the number (and, consequently, size) of forage meals for the 12 cows using the RIC feeders. Single blood samples were taken from the jugular veins of each of the 12 non-fistulated cows in the final wk of each period (between 1030 and $1200 \mathrm{~h}$ ). Blood was held on ice, and spun at $1700 \times g$ for 25 minutes at $4^{\circ} \mathrm{C}$ to separate plasma, which was decanted and stored at $-20^{\circ} \mathrm{C}$ until analysis using test kits (Moorby et al., 2000).

Diet digestibility was measured with 6-d total collections of feces from the fistulated cows in the third wk of each period, using the equipment described by Aston et al. (1998). An additional experimental period was used for digestibility and milk fatty acid measurements using the fistulated cows. Outputs of urinary $\mathrm{N}$ appeared to be erroneous and so are not reported.

Experiment 2 (silages prepared in 1999). This experiment involved 7 dietary treatments, including some repetition of treatments used in Experiment 1, but also investigating two levels of feeding of the same standard concentrate (4 or $8 \mathrm{~kg} / \mathrm{d})$. Concentrates were offered through out-of-parlor feeders in 4 equal allocations that were spaced by $4.5 \mathrm{~h}$. The dietary treatments in this experiment were: grass silage and $4 \mathrm{~kg} / \mathrm{d}$ concentrates (G4); grass silage and $8 \mathrm{~kg} / \mathrm{d}$ concentrates (G8); a 50/50 mixture (DM basis) of grass silage and red clover silage and $4 \mathrm{~kg} / \mathrm{d}$ concentrates (GRC4); a 50/50 mixture of grass silage and red clover silage (DM basis) and $8 \mathrm{~kg} / \mathrm{d}$ concentrates (GRC8); red clover silage and $4 \mathrm{~kg} / \mathrm{d}$ concentrates (RC4); red clover silage and $8 \mathrm{~kg} /$ d concentrates (RC8); white clover silage and $8 \mathrm{~kg} / \mathrm{d}$ concentrates (WC8). The forage yields obtained previously led us to concentrate on diets based on RC, though treatment WC8 was retained because this gave the highest milk yields in Experiment 1. The feeds were offered to 21 Holstein-Friesian cows in a 3-period cyclical changeover-design (Davis and Hall, 1969), with 4wk periods. The mean BW was $609(\mathrm{SD}=49.6) \mathrm{kg}$ and the mean initial DIM $82(\mathrm{SD}=15.3)$ for the 19 cows that completed the experiment. All cows were housed in a free-stall barn with ad libitum access to the forages through RIC feeders. Measurements were as described for Experiment 1, except that diet digestibilities were estimated for two blocks of cows $(n=14)$ by an indirect method using acid insoluble ash (Ministry of Agriculture, Fisheries and Food, 1986) as an internal marker, with 2 samples of feces taken on 2 consecutive days.

\section{Sampling and Chemical Analysis}

At least 3 forage samples were collected from each field immediately prior to harvesting and stored frozen $\left(-20^{\circ} \mathrm{C}\right)$, before freeze-drying and analysis for oven-DM (AOAC, 1990), CP $(\mathrm{N} \times 6.25$; Leco FP $428 \mathrm{~N}$ analyzer), water-soluble carbohydrates (Ministry of Agriculture, Fisheries and Food, 1986), nitrate (Bremner and Keeney, 1965) and buffering capacity (Playne and McDonald, 1966). Lactic acid bacteria counts were conducted according to Merry et al. (1995).

Samples of each silage (composite of 3 ) and concentrates were taken during each measurement wk, stored frozen and freeze-dried prior to chemical analysis ac- 
Table 2. Chemical composition and lactic acid bacteria counts for the crops as ensiled.

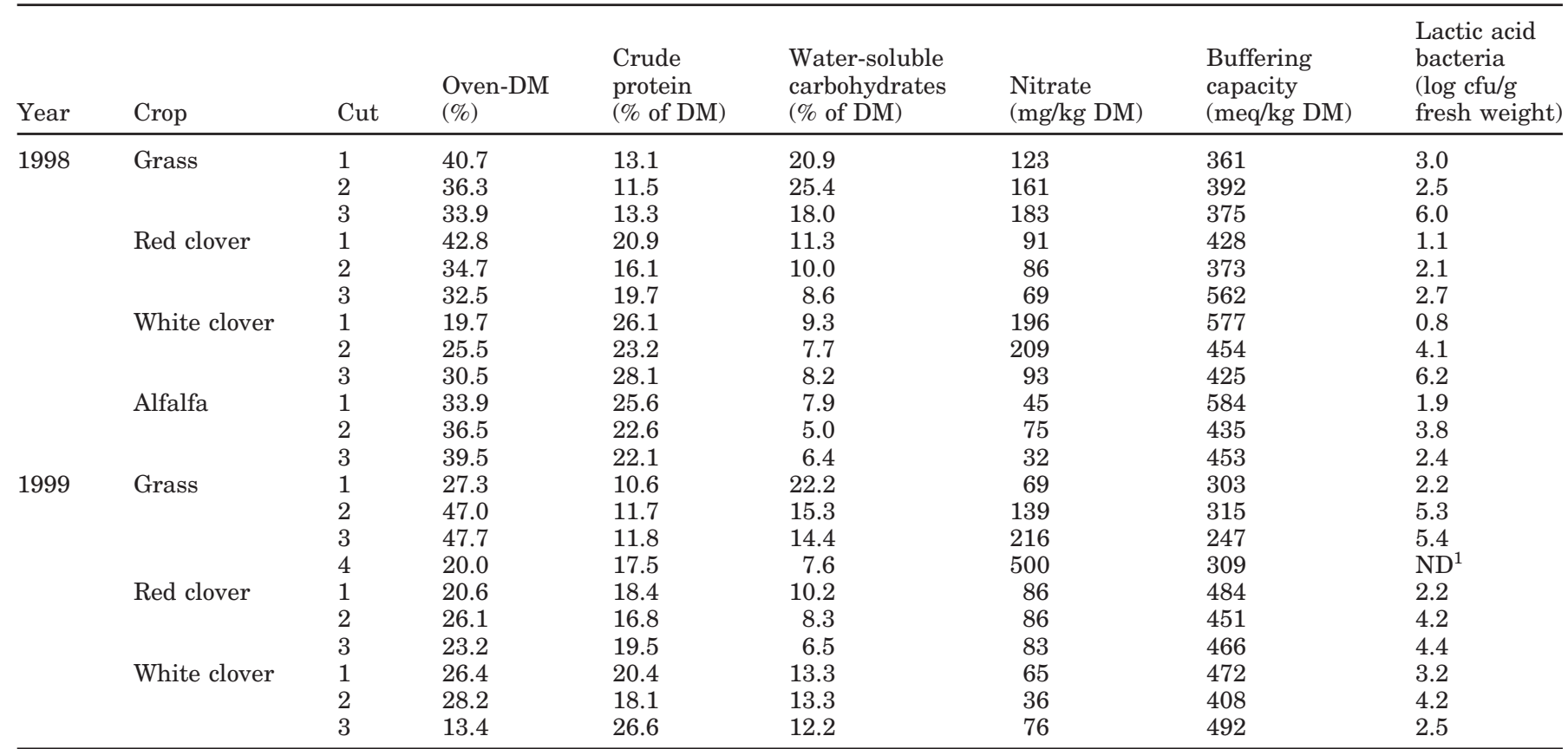

${ }^{1} \mathrm{ND}=$ not determined.

cording to the methods described by Dewhurst et al. (2000). Ethanol was determined according to the method of Fussell and McCalley (1987). All intake and chemical composition values for forages have been corrected to a freeze-DM basis.

Milk fat, protein and lactose were determined by infrared milk analyzer (Milkoscan 605, Foss Electric, Denmark). Additional milk samples were collected and stored at $-20^{\circ} \mathrm{C}$ without preservative, prior to freezedrying and analysis of fatty acids by GC as fatty acid methyl esters (FAME), which were prepared using the one-step extraction and methylation procedure of Sukhija and Palmquist (1988). For Experiment 1, a $30 \mathrm{~m}$ ZB-Wax column (Phenomenex, Macclesfield, UK ) was used to separate FAME, with nitrogen as carrier gas. The injector was held at $200^{\circ} \mathrm{C}$ and the detector at $230^{\circ} \mathrm{C}$; a temperature gradient $\left(60^{\circ} \mathrm{C}\right.$ for $3 \mathrm{~min}, 20^{\circ} \mathrm{C} /$ min rise to $230^{\circ} \mathrm{C}$, and $8.5 \mathrm{~min}$ at $230^{\circ} \mathrm{C}$ ) was used to separate the FAME. For Experiment 2, a $100 \mathrm{~m} \mathrm{CP}-$ Sil Select for FAME CB column (Varian, Walton-onThames, UK) was used, with helium as carrier gas. The injector was held at $250^{\circ} \mathrm{C}$ and the detector at $255^{\circ} \mathrm{C}$; a temperature gradient (starting at $70^{\circ} \mathrm{C}, 20^{\circ} \mathrm{C} / \mathrm{min}$ rise to $175^{\circ} \mathrm{C}$, hold for $25 \mathrm{~min}, 2.5^{\circ} \mathrm{C} / \mathrm{min}$ rise to $200^{\circ} \mathrm{C}$, hold for $2 \mathrm{~min}, 20^{\circ} \mathrm{C} / \mathrm{min}$ rise to $230^{\circ} \mathrm{C}$, hold for $8.5 \mathrm{~min}$ ) was used to separate the FAME. Fatty acid methyl esters were identified and quantified by reference to quantitative external standards (Larodan Fine Chemicals AB, Malmö, Sweden). Trans-11 $\mathrm{C}_{18: 1}$ co-eluted with cis-9
$\mathrm{C}_{18: 1}$ on the $30 \mathrm{~m}$ column. Neither $\mathrm{C}_{4: 0}$ or CLA were reported from the $30 \mathrm{~m}$ column.

\section{Statistical Analysis}

Mean values from the final wk of each period were used in the statistical analysis of feed intake, milk production, and milk composition. Analysis of variance was conducted using the restricted maximum likelihood (REML) directive of Genstat 5 for Windows (Lawes Agricultural Trust, 2000). For Experiment 1, the fixed model had 6 treatments with an embedded $2 \times 2$ factorial (50 or $100 \%$ legume silage $\times$ red clover or white clover). For Experiment 2, the fixed model was a $3 \times 2$ factorial (grass/red clover level $\times$ concentrate level) with an additional control treatment (WC8). In each case, the analysis adopted a random model of 'Period' $\times$ 'Cow'. Measurements were lost from one fistulated cow that was lame at the end of the first period of Experiment 1. One of the fistulated cows became sick (digestive upset) and was not used in the second and third periods. Two cows were lost from the second experiment for reasons unrelated to treatments (failure to use the feeding equipment) and were excluded from the analysis. The Tables show the number of cows for each dietary treatment and measurement. 
Table 3. Chemical composition of the concentrates (\% of DM, unless stated otherwise).

\begin{tabular}{lcc}
\hline & Experiment 1 & Experiment 2 \\
\hline DM $(\%)$ & 86.2 & 85.0 \\
Ash & 8.1 & 8.3 \\
Crude Protein & 21.8 & 25.0 \\
NDF & 29.7 & 24.6 \\
ADF & 15.3 & 10.9 \\
Starch & 26.9 & 23.1 \\
Water-soluble carbohydrates & 6.8 & 10.1 \\
Total fatty acids & 4.77 & 3.57 \\
C $_{16: 0}$ & 0.86 & 0.91 \\
C $_{18: 1}$ & 1.31 & 1.32 \\
C $_{18: 2}$ & 1.07 & 0.36 \\
C $_{18: 3}$ & 0.08 & 0.03 \\
\hline
\end{tabular}

\section{RESULTS}

\section{Crop Composition}

The chemical composition and lactic acid bacteria counts of the herbage 'as ensiled' are shown in Table 2 . The relatively low levels of lactic acid bacteria in many of the crops suggest that the biological inoculant was essential for successful fermentation with many of the materials. The relatively higher buffering capacity and lower content of water-soluble carbohydrates for the legume crops made them more challenging as materials to ensile.

\section{Feed Composition}

The chemical composition of the standard concentrate and silages are shown in Tables 3 and 4, respectively. Variable weather conditions meant that we produced silages with a wide range of DM contents over the course of the experiment (Table 2). Despite the composition of the material at ensiling, all of the silages were well-preserved, aerobically stable, and readily consumed by the cows. The extensive lactic fermentations of the white clover silage are noteworthy, whilst levels of butyric acid were higher in the red clover silages.

The levels and patterns of most fatty acids were similar in the different silages, with higher levels of $\alpha$ linolenic acid $\left(\mathrm{C}_{18: 3}\right)$ in white clover silage relative to grass silage (Table 5). There was no consistent pattern in levels of $\mathrm{C}_{18: 3}$ in red clover silage relative to grass silage. Table 6 shows the levels of crude protein, fiber, starch, water-soluble carbohydrates, and total fatty acids in the total diets.

\section{Animal Performance}

Intake, diet digestibility and milk production results are presented in Tables 7 (Experiment 1 ) and 8 (Experiment 2). Silage intake, silage meal size, and the yields of milk, milk protein, and milk lactose in Experiment 1 were significantly lower for cows offered grass silage in comparison with treatments that contained legumes, although there were no significant effects of clover \% or clover species on these measures. The superiority of legume silages was in contrast to differences in diet digestibility, which was highest for cows offered grass silage, lowest for cows offered alfalfa silage, reduced by increasing clover $\%$, and significantly lower for red clover in comparison with white clover. The imbalance in levels of digestible $\mathrm{N}$ and digestible DM in diet WC, and particularly in diet A, is also shown in Table 7. The efficiency of conversion of feed-N into milk-N was significantly higher for cows offered grass silage, and was progressively reduced with increasing legume content; the lowest efficiency was for cows offered alfalfa silage.

Table 4. Chemical analysis of the silages (\% of freeze-DM, unless stated otherwise).

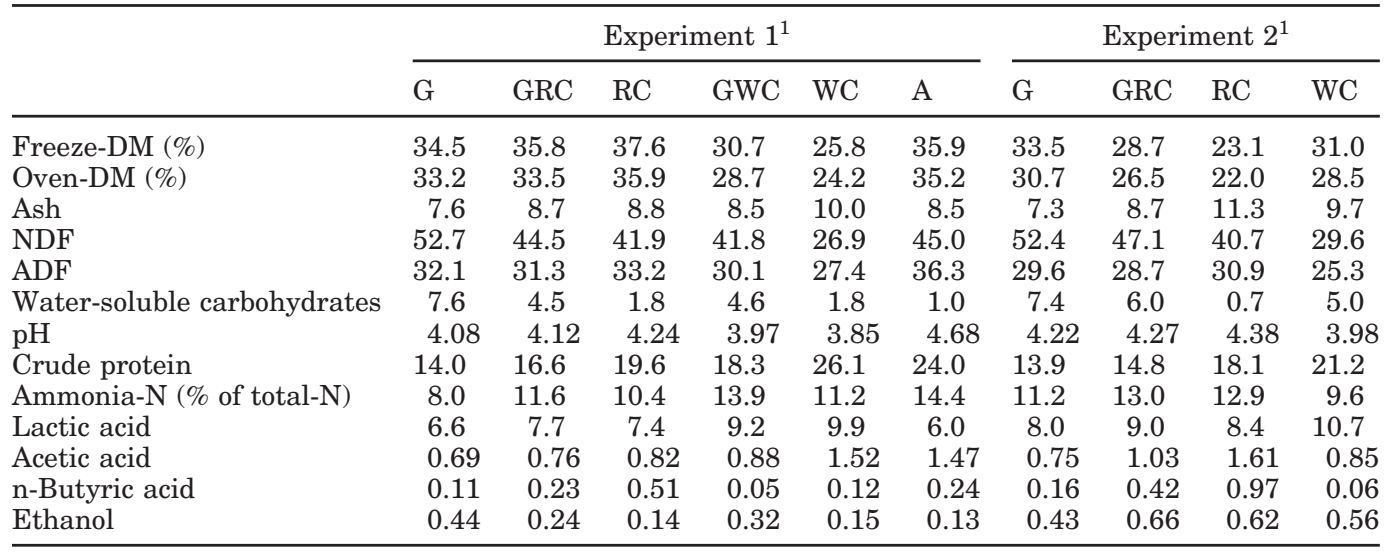

${ }^{1} \mathrm{G}=$ grass silage; $\mathrm{RC}=$ red clover silage; $\mathrm{WC}=$ white clover silage; $\mathrm{A}=$ alfalfa silage; $\mathrm{GRC}=$ mixture of $\mathrm{G}$ and $\mathrm{RC}$ (50/50, DM basis); and GWC = mixture of $\mathrm{G}$ and $\mathrm{WC}(50 / 50, \mathrm{DM}$ basis $)$. 
Table 5. Fatty acid concentrations in the silages (\% of freeze-DM).

\begin{tabular}{|c|c|c|c|c|c|c|c|c|c|c|}
\hline & \multicolumn{6}{|c|}{ Experiment $1^{1}$} & \multicolumn{4}{|c|}{ Experiment $2^{1}$} \\
\hline & $\mathrm{G}$ & GRC & $\mathrm{RC}$ & GWC & WC & A & G & GRC & $\mathrm{RC}$ & WC \\
\hline Total fatty acids & 1.52 & 1.54 & 1.55 & 1.94 & 2.63 & 1.42 & 1.32 & 1.51 & 2.00 & 2.33 \\
\hline $\mathrm{C}_{16: 0}$ & 0.30 & 0.34 & 0.37 & 0.40 & 0.53 & 0.39 & 0.29 & 0.31 & 0.38 & 0.42 \\
\hline $\mathrm{C}_{18: 2}$ & 0.24 & 0.29 & 0.37 & 0.32 & 0.46 & 0.32 & 0.22 & 0.27 & 0.40 & 0.43 \\
\hline $\mathrm{C}_{18: 3}$ & 0.77 & 0.70 & 0.62 & 1.00 & 1.41 & 0.53 & 0.71 & 0.79 & 1.04 & 1.28 \\
\hline
\end{tabular}

${ }^{1} \mathrm{G}=$ grass silage; $\mathrm{RC}=$ red clover silage; $\mathrm{WC}=$ white clover silage; $\mathrm{A}=$ alfalfa silage; $\mathrm{GRC}=$ mixture of $\mathrm{G}$ and $\mathrm{RC}(50 / 50, \mathrm{DM}$ basis $)$; and GWC = mixture of $\mathrm{G}$ and $\mathrm{WC}(50 / 50, \mathrm{DM}$ basis $)$.

Comparing results for cows offered white clover silage with all other treatments in Experiment 2 shows that it led to significantly higher silage DMI, significantly larger silage meals, and significantly higher yields of milk, milk fat, milk protein, and milk lactose. Milk from the cows offered white clover silage had a significantly lower fat percentage and a significantly higher protein percentage. The additional concentrates had the anticipated effects on performance: reduced silage DMI, increased total DMI, increased yields of milk, milk fat, milk protein, and milk lactose, and increased milk protein percentage. Increasing the level of inclusion of red clover silage led to increased DMI and increased yields of milk, milk protein, and milk lactose.

Milk fatty acid profiles are given in Tables 9 and 10 for the two experiments, respectively. White clover silage led to an increase in the proportion of shorterchain fatty acids (particularly $\mathrm{C}_{10: 0}$ and $\mathrm{C}_{12: 0}$ ) in milk from both experiments. The most notable effect on milk fatty acid percentages is the increase in levels of $\alpha$ linolenic acid $\left(\mathrm{C}_{18: 3}\right)$ in milk produced from cows consuming clover silage, particularly red clover silage in Experiment 2. A significant reduction in levels of $\mathrm{C}_{16: 0}$ in milk from cows offered red clover silage was also evident in this experiment. Odd-chain fatty acids made up 3 to $5 \%$ of milk fatty acids. The effects of diets on odd-chain fatty acids in milk were generally small.

Results of analysis of blood plasma are presented in Tables 11 and 12 for the two experiments, respectively. Levels of $\beta$-hydroxybutyrate were significantly lower in plasma from cows offered white clover silage in both experiments. The most obvious effect on plasma composition was the significant increase in levels of urea with increasing levels of legume inclusion; highest levels were obtained when feeding alfalfa silage.

\section{DISCUSSION}

\section{Feed Composition}

Despite having the same ingredient specification, there were small differences in the composition of concentrates between years. These must reflect differences between batches in the composition of raw materials, including differences in the oil content of oilseed byproducts (rapeseed, sunflower and linseed meals) and the composition of vegetable fat. The chemical analysis of the silages (Table 4) confirms the value of legumes as a source of home-grown protein, with average $\mathrm{CP}$ contents of legume silages 40 to $86 \%$ higher than in the corresponding grass silages. Some caution is needed in interpreting the chemical analysis of GRC, which was not always intermediate to $\mathrm{G}$ and $\mathrm{RC}$ - probably as a result of the difficulty of obtaining a representative sample of this mixed forage. The legume silages were all well preserved and of moderate fermentation quality, despite the high buffering capacity and relatively low water-soluble carbohydrate content of the initial herbage (Table 2). The red clover silages contained moderate levels of butyric acid, but this did not preclude good

Table 6. Chemical analysis of the total diets (\% of DM).

\begin{tabular}{|c|c|c|c|c|c|c|c|c|c|c|c|c|c|}
\hline & \multicolumn{6}{|c|}{ Experiment $1^{1}$} & \multicolumn{7}{|c|}{ Experiment $2^{1}$} \\
\hline Crude Protein & 16.9 & 18.4 & 20.3 & 19.5 & 24.6 & 23.3 & 16.1 & 17.8 & 16.7 & 18.2 & 19.3 & 20.2 & 22.3 \\
\hline $\mathrm{ADF}$ & 25.8 & 25.7 & 27.1 & 25.0 & 23.2 & 29.2 & 25.9 & 23.1 & 25.3 & 22.7 & 27.5 & 24.7 & 21.0 \\
\hline Starch & 10.2 & 9.4 & 9.2 & 9.2 & 9.4 & 9.0 & 4.5 & 8.0 & 4.4 & 7.7 & 3.9 & 7.1 & 6.8 \\
\hline Water-soluble carbohydrates & 7.30 & 5.30 & 3.50 & 5.36 & 3.55 & 2.95 & 7.93 & 8.34 & 6.78 & 7.37 & 2.30 & 3.61 & 6.51 \\
\hline Total fatty acids & 2.87 & 2.73 & 2.71 & 2.97 & 3.24 & 2.67 & 1.76 & 2.10 & 1.90 & 2.20 & 2.27 & 2.49 & 2.70 \\
\hline
\end{tabular}

${ }^{1} \mathrm{G}=$ grass silage; $\mathrm{RC}=$ red clover silage; $\mathrm{WC}=$ white clover silage; $\mathrm{A}=$ alfalfa silage; $\mathrm{GRC}=$ mixture of $\mathrm{G}$ and $\mathrm{RC}(50 / 50, \mathrm{DM}$ basis $)$; $\mathrm{GWC}=$ mixture of $\mathrm{G}$ and WC (50/50, DM basis). 
Table 7. Effects of legume silages on feed intake, meal patterns and milk production in Experiment 1. Meal patterns were recorded for two blocks of cows. Digestibilities were recorded for one block of cows.

\begin{tabular}{|c|c|c|c|c|c|c|c|c|c|c|c|}
\hline & \multicolumn{6}{|c|}{ Treatment $^{1}$} & \multirow{2}{*}{$\begin{array}{l}\text { Standard } \\
\text { error } \\
\text { of the } \\
\text { difference }\end{array}$} & \multicolumn{4}{|c|}{ Significance } \\
\hline & G & GRC & $\mathrm{RC}$ & GWC & WC & A & & Group $^{2}$ & Clover $\%^{3}$ & $\begin{array}{l}\text { Clover } \\
\text { species }^{4}\end{array}$ & Interaction $^{5}$ \\
\hline Number & 9 & 8 & 9 & 9 & 8 & 8 & & & & & \\
\hline Silage DM intake $(\mathrm{kg} / \mathrm{d})$ & 11.4 & 12.9 & 13.4 & 13.2 & 12.9 & 13.6 & 0.66 & $* * *$ & NS & NS & NS \\
\hline Total DM intake $(\mathrm{kg} / \mathrm{d})$ & 18.2 & 19.8 & 20.3 & 20.1 & 19.8 & 20.4 & 0.66 & $* * *$ & NS & NS & NS \\
\hline Milk yield $(\mathrm{kg} / \mathrm{d})$ & 24.9 & 28.6 & 28.1 & 27.9 & 31.5 & 27.7 & 1.80 & $*$ & NS & NS & NS \\
\hline $4 \%-\mathrm{FCM}(\mathrm{kg} / \mathrm{d})$ & 26.5 & 31.0 & 30.5 & 30.7 & 33.6 & 29.3 & 2.36 & * & NS & NS & NS \\
\hline Milk fat $(\%)$ & 4.45 & 4.60 & 4.52 & 4.66 & 4.39 & 4.42 & 0.249 & NS & NS & NS & NS \\
\hline Milk protein (\%) & 3.26 & 3.21 & 3.14 & 3.22 & 3.20 & 3.26 & 0.053 & NS & NS & NS & NS \\
\hline Milk lactose (\%) & 4.71 & 4.72 & 4.68 & 4.74 & 4.71 & 4.66 & 0.041 & NS & NS & NS & NS \\
\hline Milk fat $(\mathrm{g} / \mathrm{d})$ & 1102 & 1300 & 1285 & 1302 & 1400 & 1212 & 120.6 & NS & NS & NS & NS \\
\hline Milk protein (g/d) & 807 & 920 & 882 & 892 & 1006 & 891 & 58.1 & * & NS & NS & NS \\
\hline Milk lactose (g/d) & 1171 & 1350 & 1314 & 1323 & 1477 & 1299 & 84.9 & * & NS & NS & NS \\
\hline$N$ intake $(g / d)$ & 507 & 558 & 689 & 618 & 784 & 778 & 28.0 & $* * *$ & $* * *$ & $* * *$ & NS \\
\hline $\mathrm{N}$ efficiency (milk-N/feed-N, \%) & 25.6 & 24.5 & 21.0 & 22.2 & 20.5 & 18.2 & 1.51 & $* * *$ & $*$ & NS & NS \\
\hline Number & 6 & 6 & 6 & 6 & 6 & 6 & & & & & \\
\hline Number of silage meals/d & 7.9 & 7.8 & 8.1 & 6.2 & 7.6 & 6.4 & 1.36 & NS & NS & NS & NS \\
\hline Silage meal size (kg DM) & 1.68 & 1.72 & 1.99 & 2.24 & 1.80 & 2.22 & 0.255 & $\dagger$ & NS & NS & $\dagger$ \\
\hline Number & 4 & 3 & 3 & 4 & 3 & 4 & & & & & \\
\hline DM digestibility $(\%)(\dagger)$ & 72.0 & 68.7 & 64.9 & 71.9 & 68.7 & 64.0 & 0.94 & $* * *$ & $* * *$ & $* * *$ & NS \\
\hline $\mathrm{N}$ digestibility $(\%)(\dagger)$ & 72.6 & 66.8 & 65.0 & 71.3 & 71.5 & 71.5 & 2.17 & * & NS & $* * *$ & NS \\
\hline ND/DMD ratio $(\dagger)$ & 1.02 & 0.99 & 1.02 & 1.01 & 1.06 & 1.13 & 0.032 & $* * *$ & $\dagger$ & NS & NS \\
\hline
\end{tabular}

${ }^{1} \mathrm{G}=$ grass silage; $\mathrm{RC}=$ red clover silage; $\mathrm{WC}=$ white clover silage; $\mathrm{A}=$ alfalfa silage; $\mathrm{GRC}=$ mixture of $\mathrm{G}$ and $\mathrm{RC}(50 / 50, \mathrm{DM}$ basis $)$; $\mathrm{GWC}=$ mixture of $\mathrm{G}$ and $\mathrm{WC}(50 / 50$, DM basis).

${ }^{2}$ Group $=$ G vs. A vs. clover-containing diets (3-way comparison).

${ }^{3}$ Clover $\%=50$ vs. $100 \%$ clover (within clover-containing diets)

${ }^{4}$ Clover species $=\mathrm{RC}$ vs. WC (within clover-containing diets).

${ }^{5}$ Clover $\% \times$ clover species interaction.

$\mathrm{NS}=$ not significant $(P>0.1) ; \dagger P<0.1 ; * P<0.05 ; * * P<0.01 ; * * * P<0.001$ 
Table 8. Effects of legume silages on feed intake, meal patterns and milk production (Experiment 2).

\begin{tabular}{|c|c|c|c|c|c|c|c|c|c|c|c|}
\hline & \multicolumn{7}{|c|}{ Treatment $^{1}$} & \multirow{2}{*}{$\begin{array}{l}\text { Standard } \\
\text { error } \\
\text { of the } \\
\text { difference }\end{array}$} & \multicolumn{3}{|c|}{ Significance } \\
\hline & G4 & G8 & GRC4 & GRC8 & $\mathrm{RC} 4$ & $\mathrm{RC} 8$ & WC8 & & $\begin{array}{l}\text { White } \\
\text { clover }^{2}\end{array}$ & $\begin{array}{l}\% \text { Red } \\
\text { clover }^{3}\end{array}$ & $\begin{array}{l}\text { Concentrate } \\
\text { level }^{4}\end{array}$ \\
\hline Number & 8 & 8 & 8 & 9 & 7 & 8 & 9 & & & & \\
\hline Silage DM intake $(\mathrm{kg} / \mathrm{d})$ & 14.0 & 12.6 & 14.5 & 13.5 & 16.6 & 15.2 & 15.9 & 0.61 & $* *$ & $* * *$ & $* * *$ \\
\hline Number of silage meals/d & 9.5 & 9.4 & 9.5 & 8.4 & 11.3 & 8.9 & 8.0 & 1.25 & $\dagger$ & NS & NS \\
\hline Silage meal size (kg DM) & 1.58 & 1.46 & 1.67 & 1.69 & 1.70 & 1.80 & 2.06 & 0.185 & $* *$ & $\dagger$ & NS \\
\hline Total DM intake $(\mathrm{kg} / \mathrm{d})$ & 17.4 & 19.3 & 17.9 & 20.3 & 20.0 & 22.0 & 22.6 & 0.62 & $* * *$ & $* * *$ & $* * *$ \\
\hline Diet digestibility $(\%)$ & 65.5 & 68.2 & 69.0 & 66.5 & 66.9 & 67.6 & 67.8 & 3.29 & NS & NS & NS \\
\hline Milk (kg/d) & 23.5 & 27.5 & 23.7 & 28.6 & 25.6 & 30.2 & 33.2 & 0.83 & $* * *$ & $* * *$ & $* * *$ \\
\hline $4 \%-\mathrm{FCM}(\mathrm{kg} / \mathrm{d})$ & 22.5 & 27.6 & 22.7 & 27.8 & 25.2 & 28.8 & 30.8 & 1.18 & $* * *$ & * & $* * *$ \\
\hline Milk fat $(\%)$ & 3.73 & 4.10 & 3.67 & 3.79 & 3.91 & 3.74 & 3.52 & 0.186 & $*$ & NS & NS \\
\hline Milk protein (\%) & 2.98 & 3.04 & 2.98 & 3.11 & 2.94 & 2.97 & 3.17 & 0.049 & $* * *$ & $*$ & $* *$ \\
\hline Milk lactose (\%) & 4.62 & 4.59 & 4.56 & 4.60 & 4.62 & 4.61 & 4.60 & 0.049 & NS & NS & NS \\
\hline Milk fat (g/d) & 870 & 1103 & 886 & 1087 & 987 & 1124 & 1169 & 65.1 & $* * *$ & NS & $* * *$ \\
\hline Milk protein $(\mathrm{g} / \mathrm{d})$ & 693 & 832 & 712 & 887 & 746 & 894 & 1045 & 31.5 & $* * *$ & * & $* * *$ \\
\hline Milk lactose $(\mathrm{g} / \mathrm{d})$ & 1086 & 1259 & 1081 & 1319 & 1185 & 1391 & 1521 & 37.1 & $* * *$ & $* * *$ & $* * *$ \\
\hline $\mathrm{N}$ intake $(\mathrm{g} / \mathrm{d})$ & 448 & 551 & 475 & 591 & 616 & 711 & 809 & 18.4 & $* * *$ & $* * *$ & $* * *$ \\
\hline $\mathrm{N}$ efficiency (milk-N/feed-N; \%) & 24.2 & 23.5 & 24.0 & 23.4 & 18.8 & 19.7 & 20.4 & 0.80 & $* * *$ & **** & NS \\
\hline
\end{tabular}

${ }^{1} \mathrm{G} 4=$ grass silage with $4 \mathrm{~kg} / \mathrm{d}$ concentrates; G8 = grass silage with $8 \mathrm{~kg} / \mathrm{d}$ concentrates; GRC4 = grass silage/red clover silage mix (50/50, DM basis) with $4 \mathrm{~kg} / \mathrm{d}$ concentrates; GRC8 = grass silage/red clover silage mix (50/50, DM basis) with $8 \mathrm{~kg} / \mathrm{d}$ concentrates; RC4 = red clover silage with $4 \mathrm{~kg} / \mathrm{d}$ concentrates; RC8 = red clover silage with $8 \mathrm{~kg} / \mathrm{d}$ concentrates: WC8 = white clover silage with $8 \mathrm{~kg} / \mathrm{d}$ concentrates.

NS = not significant $(P>0.1) ; \dagger<0.1 ; * P<0.05 ; * * P<0.01 ; * * * P<0.001$

${ }^{2} \mathrm{WC} 8$ in comparison with all other treatments.

$3 \%$ Red clover (within the treatments containing grass and/or red clover silage).

${ }^{4}$ Concentrate feeding level (4 vs. $8 \mathrm{~kg} / \mathrm{d}$ ) within the treatments containing grass and/or red clover silage. There were no significant $\%$ Red clover $\times$ concentrate level interactions $(P<0.05)$. 
Table 9. Effects of legume silages on the fatty acid composition of milk (\% of total milk fatty acids ${ }^{6}$ ) and apparent recovery of $\mathrm{C}_{18: 2}$ and $\mathrm{C}_{18: 3}$ from feed to milk (\%). Results are for one block of cows in Experiment 1

\begin{tabular}{|c|c|c|c|c|c|c|c|c|c|c|c|}
\hline & \multicolumn{6}{|c|}{ Treatment $^{1}$} & \multirow{2}{*}{$\begin{array}{l}\text { Standard } \\
\text { error } \\
\text { of the } \\
\text { difference }\end{array}$} & \multicolumn{4}{|c|}{ Significance } \\
\hline & $\mathrm{G}$ & GRC & $\mathrm{RC}$ & GWC & WC & $\mathrm{A}$ & & Group $^{2}$ & Clover $\%^{3}$ & $\begin{array}{l}\text { Clover } \\
\text { species }^{4}\end{array}$ & Interaction $^{5}$ \\
\hline Number & 4 & 4 & 3 & 4 & 3 & 3 & & & & & \\
\hline $\mathrm{C}_{6: 0}$ & 2.76 & 2.61 & 2.73 & 2.77 & 2.81 & 2.62 & 0.100 & NS & NS & $\dagger$ & NS \\
\hline $\mathrm{C}_{8: 0}$ & 1.91 & 1.83 & 1.90 & 1.98 & 2.04 & 1.83 & 0.073 & NS & NS & $* *$ & NS \\
\hline $\mathrm{C}_{10: 0}$ & 3.32 & 3.26 & 3.32 & 3.54 & 3.74 & 3.20 & 0.162 & NS & NS & $* *$ & NS \\
\hline $\mathrm{C}_{12: 0}$ & 4.26 & 4.29 & 4.28 & 4.48 & 4.73 & 4.27 & 0.222 & NS & NS & $*$ & NS \\
\hline $\mathrm{C}_{14: 0}$ & 12.2 & 12.1 & 12.2 & 12.4 & 13.0 & 11.7 & 0.46 & NS & NS & $\dagger$ & NS \\
\hline $\mathrm{C}_{14: 1}$ & 1.47 & 1.34 & 1.26 & 1.33 & 1.33 & 1.33 & 0.093 & $\dagger$ & NS & NS & NS \\
\hline $\mathrm{C}_{16: 0}$ & 31.5 & 30.0 & 31.2 & 31.0 & 29.7 & 28.9 & 0.85 & * & NS & NS & ** \\
\hline $\mathrm{C}_{16: 1}$ & 2.32 & 2.11 & 2.10 & 2.07 & 2.02 & 2.10 & 0.097 & $* *$ & NS & NS & NS \\
\hline $\mathrm{C}_{18: 0}$ & 10.5 & 10.0 & 10.1 & 10.1 & 9.9 & 9.5 & 0.55 & NS & NS & NS & NS \\
\hline $\mathrm{C}_{18: 1}$ & 24.7 & 23.7 & 24.0 & 22.7 & 23.0 & 23.3 & 1.02 & NS & NS & NS & NS \\
\hline $\mathrm{C}_{18: 2}$ & 1.42 & 1.69 & 1.81 & 1.45 & 1.80 & 1.61 & 0.112 & $* *$ & $* *$ & $\dagger$ & NS \\
\hline $\mathrm{C}_{18: 3}$ & 0.43 & 0.53 & 0.81 & 0.53 & 0.91 & 0.54 & 0.090 & $* * *$ & $* * *$ & NS & NS \\
\hline $\mathrm{C}_{18.3}: \mathrm{C}_{18 \cdot 2}$ ratio & 0.30 & 0.32 & 0.45 & 0.36 & 0.50 & 0.34 & 0.042 & $* *$ & $* * *$ & NS & NS \\
\hline Apparent recovery of $\mathrm{C}_{18: 2}$ from feed to milk (\%) & 11.7 & 10.9 & 12.1 & 11.6 & 13.0 & 10.3 & 0.95 & NS & $\dagger$ & NS & NS \\
\hline Apparent recovery of $\mathrm{C}_{18: 3}$ from feed to milk (\%) & 3.80 & 4.30 & 7.86 & 3.40 & 4.13 & 5.49 & 0.70 & ** & $* * *$ & $* * *$ & $* *$ \\
\hline
\end{tabular}

${ }^{1} \mathrm{G}=$ grass silage; $\mathrm{RC}=$ red clover silage; $\mathrm{WC}=$ white clover silage; $\mathrm{A}=$ alfalfa silage; $\mathrm{GRC}=$ mixture of $\mathrm{G}$ and $\mathrm{RC}(50 / 50$, DM basis $)$ and $\mathrm{GWC}=$ mixture of $\mathrm{G}$ and $\mathrm{WC}$ (50/50, DM basis).

${ }^{2}$ Group $=$ G vs. A vs. clover-containing diets (3-way comparison).

${ }^{3}$ Clover $\%=50$ vs. $100 \%$ clover (within clover-containing diets)

${ }^{4}$ Clover species $=\mathrm{RC}$ vs. WC (within clover-containing diets).

${ }^{5}$ Clover $\% \times$ clover species interaction.

${ }^{6}$ Total fatty acids included $\mathrm{C}_{15 \cdot 0}$, anteiso $\mathrm{C}_{15 \cdot 0}$, iso $\mathrm{C}_{15 \cdot 0}, \mathrm{C}_{17 \cdot 0}$, anteiso $\mathrm{C}_{17 \cdot 0}$, iso $\mathrm{C}_{17 \cdot 0}, \mathrm{C}_{17 \cdot 1}$ and $\mathrm{C}_{20 \cdot 0}$ in addition to those listed.

$\mathrm{NS}=$ not significant $(P>0.1) ; \dagger P<0.1 ; * P<0.05 ; * * P<0.01 ; * * * P<0.001$. 
Table 10. Effects of legume silages on the fatty acid composition of milk (\% of total milk fatty acids ${ }^{6}$ ) and apparent recovery of $\mathrm{C}_{18: 2}$ and $\mathrm{C}_{18: 3}$ from feed to milk (\%) (Experiment 2).

\begin{tabular}{|c|c|c|c|c|c|c|c|c|c|c|c|c|}
\hline & \multicolumn{7}{|c|}{ Treatment $^{1}$} & \multirow{2}{*}{$\begin{array}{l}\text { Standard } \\
\text { error } \\
\text { of the } \\
\text { difference }\end{array}$} & \multicolumn{4}{|c|}{ Significance } \\
\hline & G4 & G8 & GRC4 & GRC8 & $\mathrm{RC} 4$ & $\mathrm{RC} 8$ & WC8 & & $\begin{array}{l}\text { White } \\
\text { clover }^{2}\end{array}$ & $\begin{array}{l}\% \text { Red } \\
\text { clover }^{3}\end{array}$ & $\begin{array}{l}\text { Concentrate } \\
\text { level }^{4}\end{array}$ & Interaction $^{5}$ \\
\hline Number & 8 & 8 & 8 & 9 & 7 & 8 & 9 & & & & & \\
\hline $\mathrm{C}_{4: 0}$ & 4.89 & 4.91 & 4.91 & 5.26 & 5.54 & 5.78 & 5.16 & 0.155 & NS & $* * *$ & * & NS \\
\hline $\mathrm{C}_{6: 0}$ & 2.71 & 2.69 & 2.65 & 2.95 & 2.78 & 2.98 & 3.04 & 0.093 & $* * *$ & $*$ & $* *$ & $*$ \\
\hline $\mathrm{C}_{8: 0}$ & 1.33 & 1.36 & 1.26 & 1.46 & 1.29 & 1.43 & 1.57 & 0.056 & $* * *$ & NS & $* * *$ & $\dagger$ \\
\hline $\mathrm{C}_{10: 0}$ & 2.91 & 2.95 & 2.61 & 3.08 & 2.54 & 2.83 & 3.47 & 0.141 & $* * *$ & $\dagger$ & $* * *$ & $\dagger$ \\
\hline $\mathrm{C}_{12: 0}$ & 3.34 & 3.52 & 3.01 & 3.65 & 2.89 & 3.31 & 4.16 & 0.159 & $* * *$ & * & $* * *$ & NS \\
\hline $\mathrm{C}_{14: 0}$ & 12.0 & 11.7 & 11.3 & 12.1 & 10.9 & 11.3 & 12.7 & 0.37 & $* * *$ & $*$ & NS & $\dagger$ \\
\hline $\mathrm{C}_{14: 1}$ & 1.00 & 1.06 & 1.00 & 1.03 & 0.83 & 0.86 & 1.07 & 0.056 & $* *$ & $* * *$ & NS & NS \\
\hline $\mathrm{C}_{15.0}$ & 1.30 & 1.08 & 1.37 & 1.14 & 1.41 & 1.21 & 1.28 & 0.043 & NS & $* *$ & $* * *$ & NS \\
\hline anteiso $\mathrm{C}_{15: 0}$ & 0.48 & 0.45 & 0.50 & 0.47 & 0.47 & 0.45 & 0.44 & 0.018 & $*$ & NS & $* *$ & NS \\
\hline iso $_{15: 0}$ & 0.27 & 0.25 & 0.26 & 0.24 & 0.22 & 0.21 & 0.18 & 0.009 & $* * *$ & $* * *$ & $* * *$ & NS \\
\hline $\mathrm{C}_{16: 0}$ & 34.3 & 32.5 & 34.4 & 32.8 & 31.8 & 30.6 & 32.9 & 0.94 & NS & $* * *$ & $* *$ & NS \\
\hline $\mathrm{C}_{16: 1}$ & 1.43 & 1.54 & 1.46 & 1.30 & 1.22 & 1.17 & 1.29 & 0.086 & NS & $* * *$ & NS & $\dagger$ \\
\hline $\mathrm{C}_{17: 0}$ & 0.62 & 0.53 & 0.64 & 0.52 & 0.66 & 0.57 & 0.56 & 0.023 & NS & $* *$ & $* * *$ & NS \\
\hline anteiso $\mathrm{C}_{17: 0}$ & 0.42 & 0.42 & 0.44 & 0.40 & 0.40 & 0.40 & 0.38 & 0.015 & $* *$ & $\dagger$ & NS & NS \\
\hline iso $_{17: 0}$ & 0.28 & 0.26 & 0.26 & 0.25 & 0.26 & 0.25 & 0.23 & 0.011 & $* * *$ & $*$ & $*$ & NS \\
\hline $\mathrm{C}_{18: 0}$ & 10.7 & 11.0 & 10.4 & 11.1 & 11.6 & 11.6 & 9.7 & 0.49 & $* * *$ & $*$ & NS & NS \\
\hline $\mathrm{C}_{18: 1}(c i s-9$ and cis-11) & 19.0 & 20.7 & 19.6 & 18.5 & 20.0 & 20.2 & 17.9 & 1.12 & $*$ & NS & NS & NS \\
\hline $\mathrm{C}_{18: 2}$ & 0.90 & 1.05 & 1.08 & 1.18 & 1.47 & 1.58 & 1.54 & 0.047 & $* * *$ & $* * *$ & $* * *$ & $\dagger$ \\
\hline CLA (cis-9, trans-11) & 0.37 & 0.36 & 0.45 & 0.39 & 0.42 & 0.41 & 0.34 & 0.032 & $*$ & $*$ & NS & NS \\
\hline CLA (trans-10, cis-12) & 0.025 & 0.025 & 0.035 & 0.032 & 0.035 & 0.033 & 0.031 & 0.0044 & NS & * & NS & NS \\
\hline TVA & 1.16 & 1.13 & 1.38 & 1.25 & 1.31 & 1.25 & 1.06 & 0.082 & $* *$ & * & NS & NS \\
\hline $\mathrm{C}_{18: 3}$ & 0.48 & 0.40 & 0.77 & 0.64 & 1.51 & 1.28 & 0.96 & 0.044 & $* * *$ & $* * *$ & $* * *$ & NS \\
\hline $\mathrm{C}_{20: 0}$ & 0.17 & 0.18 & 0.18 & 0.19 & 0.19 & 0.19 & 0.16 & 0.007 & $* * *$ & NS & NS & NS \\
\hline $\mathrm{C}_{18: 3}: \mathrm{C}_{18: 2}$ ratio & 0.54 & 0.37 & 0.72 & 0.55 & 1.04 & 0.81 & 0.63 & 0.027 & $*$ & $* * *$ & $* * *$ & NS \\
\hline Apparent recovery of $\mathrm{C}_{18: 2}$ from feed to milk (\%) & 19.8 & 23.4 & 20.4 & 22.3 & 18.9 & 21.8 & 20.5 & 1.46 & NS & NS & $* * *$ & NS \\
\hline Apparent recovery of $\mathrm{C}_{18: 3}$ from feed to milk (\%) & 4.52 & 5.14 & 6.56 & 7.02 & 8.90 & 9.66 & 5.90 & 0.507 & $* *$ & $* * *$ & $*$ & NS \\
\hline
\end{tabular}

${ }^{1} \mathrm{G} 4$ = grass silage with $4 \mathrm{~kg} / \mathrm{d}$ concentrates; G8 = grass silage with $8 \mathrm{~kg} / \mathrm{d}$ concentrates; GRC4 = grass silage/red clover silage mix (50/50, DM basis) with $4 \mathrm{~kg} / \mathrm{d}$ concentrates; GRC $8=$ grass silage/red clover silage mix $(50 / 50$, DM basis $)$ with $8 \mathrm{~kg} / \mathrm{d}$ concentrates; RC4 = red clover silage with $4 \mathrm{~kg} / \mathrm{d}$ concentrates; RC $8=$ red clover silage with $8 \mathrm{~kg} / \mathrm{d}$ concentrates; WC8 = white clover silage with $8 \mathrm{~kg} / \mathrm{d}$ concentrates; CLA = conjugated linoleic acid; TVA = trans-vaccenic acid.

${ }^{2} \mathrm{WC} 8$ in comparison with all other treatments.

${ }^{3} \%$ Red clover (within the treatments containing grass and/or red clover silage).

${ }^{4}$ Concentrate feeding level (4 vs. $8 \mathrm{~kg} / \mathrm{d}$ ) within the treatments containing grass and/or red clover silage.

$5 \%$ Red clover $\times$ concentrate level interaction.

${ }^{6}$ Total milk fatty acids are all those included in this Table.

$\mathrm{NS}=$ not significant $(P>0.1) ; \dagger P<0.1 ; * P<0.05 ; * * P<0.01 ; * * * P<0.001$. 
Table 11. Effects of legume silages on plasma metabolite concentrations. Results are for two blocks of cows in Experiment 1.

\begin{tabular}{|c|c|c|c|c|c|c|c|c|c|c|}
\hline & \multicolumn{6}{|c|}{ Treatment $^{1}$} & \multirow{2}{*}{$\begin{array}{l}\text { Standard } \\
\text { error } \\
\text { of the } \\
\text { difference }\end{array}$} & \multicolumn{3}{|c|}{ Significance } \\
\hline & G & GRC & $\mathrm{RC}$ & GWC & WC & A & & Group $^{2}$ & Clover $\%^{3}$ & $\begin{array}{l}\text { Clover } \\
\text { species }^{4}\end{array}$ \\
\hline Number & 6 & 6 & 6 & 6 & 6 & 6 & & & & \\
\hline Glucose $(\mathrm{mmol} / \mathrm{L})$ & 3.62 & 4.08 & 4.29 & 4.25 & 4.24 & 4.59 & 0.313 & $* *$ & NS & NS \\
\hline$\beta$-hydroxybutyrate (mmol/L) & 0.81 & 0.86 & 0.90 & 0.64 & 0.69 & 0.81 & 0.125 & NS & NS & * \\
\hline Urea $(\mathrm{mmol} / \mathrm{L})$ & 6.52 & 7.60 & 8.19 & 7.93 & 8.73 & 10.40 & 0.881 & $* * *$ & NS & NS \\
\hline Total protein (g/L) & 102.4 & 106.5 & 113.7 & 109.2 & 98.5 & 124.0 & 9.13 & $*$ & NS & NS \\
\hline Albumin $(\mathrm{g} / \mathrm{L})$ & 52.6 & 55.6 & 56.6 & 57.1 & 50.6 & 61.2 & 4.66 & NS & NS & NS \\
\hline
\end{tabular}

${ }^{1} \mathrm{G}=$ grass silage; $\mathrm{RC}=$ red clover silage; $\mathrm{WC}=$ white clover silage; $\mathrm{A}=$ alfalfa silage; $\mathrm{GRC}=$ mixture of $\mathrm{G}$ and $\mathrm{RC}(50 / 50, \mathrm{DM}$ basis $) ;$ $\mathrm{GWC}=$ mixture of $\mathrm{G}$ and WC (50/50, DM basis).

${ }^{2}$ Group = G vs. A vs. clover-containing diets (3-way comparison).

${ }^{3}$ Clover $\%=50$ vs. $100 \%$ clover (within clover-containing diets).

${ }^{4}$ Clover species $=$ RC vs. WC $($ within clover-containing diets). There were no significant clover $\% \times$ clover species interactions $(P<0.05)$.

NS, not significant $(P>0.05) ;{ }^{*} P<0.05 ; * * P<0.01 ; * * * P<0.001$.

levels of intake and milk production. There were no problems with aerobic deterioration of the silages, whether prepared from grass or legumes. Observation of discarded silages suggested particularly high aerobic stability of the legume silages- in agreement with observations in parallel laboratory-scale studies (Pahlow et al., 2002) and in other feeding experiments with alfalfa silage (McAllister et al., 1998).

\section{Feed Intake and Meal Patterns}

Both experiments (Tables 7 and 8) confirmed the higher levels of voluntary intake of legume silages in comparison with grass silages observed previously (e.g. Thomas et al., 1985; Hoffman et al., 1998). The RIC feeders enabled us to define meals (Tolkamp et al., 1998) and suggest that the increased intakes of legume silages are associated with a similar number of larger meals. The physiological basis of these effects is further discussed, in relation to the kinetics of rumen digestion and passage, in the companion paper (Dewhurst et al., 2003).

The decline in forage DM intake in response to the $4 \mathrm{~kg} / \mathrm{d}$ increase in concentrate allocation was similar for G, GRC and RC treatments in Experiment 2; substitution rates were $-0.41,-0.29$, and $-0.41 \mathrm{~kg} / \mathrm{kg}$, respectively. The additional concentrates led to increases in CP intake of 630, 703, and $597 \mathrm{~g} / \mathrm{d}$ for G, GRC, and RC, respectively. The fact that similar responses to concentrates occurred despite the widely different CP supply at the lower level of concentrate feeding $(2796,2981$, and $3855 \mathrm{~g} / \mathrm{d}$ for G4, GRC4, and RC4) confirms that protein supply had little part in the responses observed in these studies.

\section{Milk Production and Composition}

The higher DM intake of legume silages compared with grass silage was reflected in higher yields of milk, milk fat, milk protein, and milk lactose (Tables 7 and 8), though increases in milk protein yield were quite small, other than for animals receiving white clover silage. The yields of milk obtained from alfalfa silage were low relative to the high DM intake and this may reflect the higher ADF content (Table 5) and lower digestibility (Table 7) of this diet. Previous studies have also highlighted the superiority of red clover silage over alfalfa silage in relation to milk yield relative to intake (Hoffman et al., 1997 (Experiment 2); Broderick et al., 2001). Similarly, Broderick et al. (2000) estimated that red clover silage contained $10 \%$ more $\mathrm{NE}_{\mathrm{L}}$ than alfalfa silage. The use of mixtures of cuts in each silage treatment, as well as the similarity of responses between year, confirms the reliability of the intake and milk production responses recorded. The additional yield of milk in response to a supplementation of $4 \mathrm{~kg} / \mathrm{d}$ of concentrates was similar for G, GRC and RC, reflecting the similar substitution rates noted above.

This work provides new information on the effects of legume silages on milk fatty acids (Tables 9 and 10). Milk from cows offered legume silages generally contains higher levels of polyunsaturated fatty acids that are regarded as beneficial for human health (linoleic acid, conjugated linoleic acid, and $\alpha$-linolenic acid). These experiments also showed that alfalfa and red clover silage can lead to some improvement in the saturated fatty acid content of milk (Tables 9 and 10). There was no consistent effect on stearic acid $\left(\mathrm{C}_{18: 0}\right)$, which is regarded as neutral in its effect on plasma cholesterol in humans (Yu et al., 1995), but a significant reduction in palmitic acid $\left(\mathrm{C}_{16: 0}\right)$ which is known to increase plasma cholesterol in humans (Yu et al., 1995). At the low level of concentrate feeding $(4 \mathrm{~kg} / \mathrm{d})$, we observed a 3 -fold increase in the level of $\alpha$-linolenic acid in milk from cows offered red clover silage in comparison with cows offered grass silage. The increase in $n-3$ fatty acid 
Table 12. Effects of legume silages on plasma metabolite concentrations (Experiment 2).

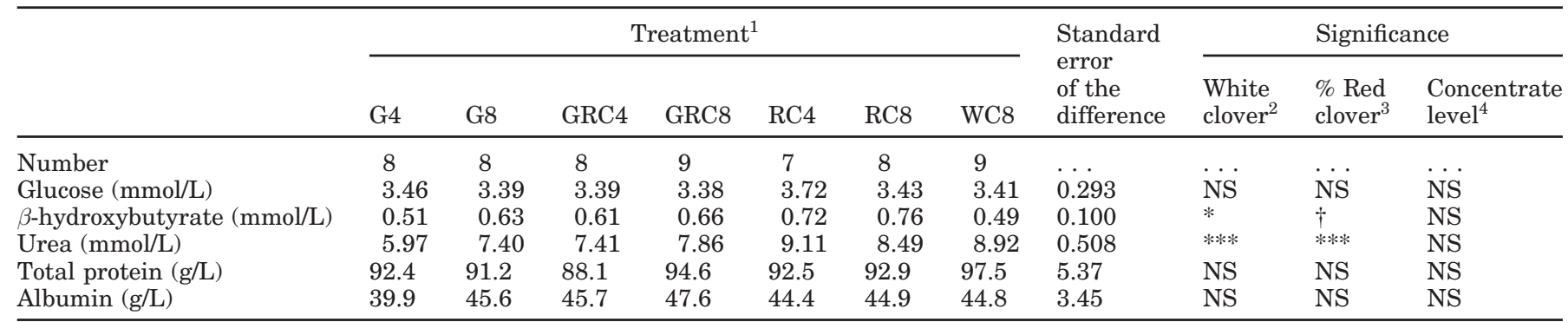

${ }^{1} \mathrm{G} 4$ = grass silage with $4 \mathrm{~kg} / \mathrm{d}$ concentrates; G8 = grass silage with $8 \mathrm{~kg} / \mathrm{d}$ concentrates; GRC4 = grass silage/red clover silage mix $(50 /$ 50 , DM basis) with $4 \mathrm{~kg} / \mathrm{d}$ concentrates; GRC 8 = grass silage/red clover silage mix (50/50, DM basis) with $8 \mathrm{~kg} / \mathrm{d}$ concentrates; RC4 = red clover silage with $4 \mathrm{~kg} / \mathrm{d}$ concentrates; RC 8 = red clover silage with $8 \mathrm{~kg} / \mathrm{d}$ concentrates; WC 8 = white clover silage with $8 \mathrm{~kg} / \mathrm{d}$ concentrates.

${ }^{2} \mathrm{WC} 8$ in comparison with all other treatments.

$3 \%$ Red clover (within the treatments containing grass and/or red clover silage).

${ }^{4}$ Concentrate feeding level (4 vs. $8 \mathrm{~kg} / \mathrm{d}$ ) within the treatments containing grass and/or red clover silage. There were no significant \% Red clover $\times$ concentrate level interactions $(P<0.05)$.

$\mathrm{NS}=$ not significant $(P>0.1) ; \uparrow P<0.1 ; * P<0.05 ; * * * P<0.001$.

( $\alpha$-linolenic acid) content is particularly valuable given the growing perception of the need to reverse the decline in the $n-3 / n-6$ fatty acid ratio in our diet (Simopoulos, 2001). The increase in polyunsaturated fatty acids in milk from cows offered white clover is in line with the higher intakes (Tables 7 and 8) and higher levels of these fatty acids in white clover silage (Table 5). The mechanism is very different with red clover silage, which contained similar levels of $\alpha$-linolenic acid to grass silage (Table 5). For Experiment 2, the apparent recovery of $\alpha$-linolenic acid from the diet into milk was $9.7 \%$ for diet RC8, in comparison with $5.9 \%$ for WC8 and $5.1 \%$ for G8. The substantial increases in polyunsaturated fatty acids in milk from cows offered red clover silage must reflect reduced rumen biohydrogenation (see Dewhurst et al., 2003). Other studies (Dewhurst and King, 1998) have shown that wilting is an important source of loss of polyunsaturated fatty acids in silage and since the red clover silages in this work were usually subject to $2 \mathrm{~d}$ of field wilting, there is clearly potential for further increases in this area. In another aspect of our work with $\alpha$-linolenic acid (from linseed oil) we have shown beneficial effects on fertility (Petit et al., 2001, 2002). We hypothesize that these mechanisms could explain the improvements in fertility of cows consuming red clover silage in earlier work (Austin et al., 1982; Thomas et al., 1985), which occurred despite evidence (from sheep) that phytoestrogens from red clover can impair fertility (Austin et al 1982).

\section{Nitrogen Utilization}

The primary objective of this work was to evaluate forages against a standard level and type of concentrate allocation, which was designed to balance the protein content of the grass silages. This limits the interpretation of the $\mathrm{N}$ utilization results, since $\mathrm{N}$ intake varied considerably between treatment groups (Tables 7 and 8). Nonetheless, taking into account these differences there are still clear areas of interest (Figure 1). The results presented in Table 8 suggest that increasing the level of concentrate feeding from $4 \mathrm{~kg} / \mathrm{d}$ to $8 \mathrm{~kg} / \mathrm{d}$ had no effect on $\mathrm{N}$ efficiency. However, when $\mathrm{N}$ intake is taken into account (Figure 1), an increase in efficiency with increased concentrate feeding becomes apparent. Although $\mathrm{N}$ intake and urinary $\mathrm{N}$ were highest for cows offered white clover silage, these cows exhibited a considerable (25\%) increase in milk protein yield, so that $\mathrm{N}$ efficiency was not as low as may have been expected.

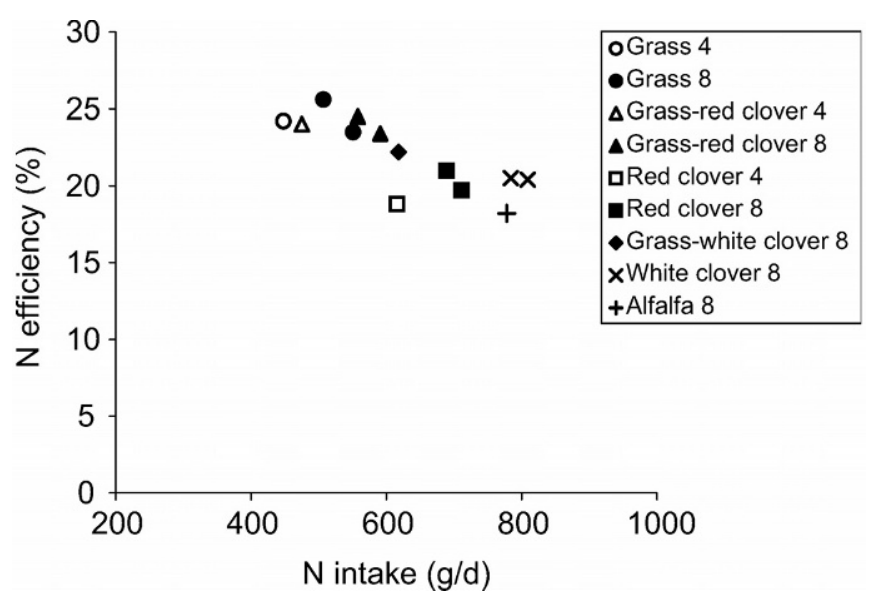

Figure 1. Efficiency of conversion of feed $\mathrm{N}$ into milk N (\%) for the forage treatments in Experiments 1 and 2 (grass silage, red clover silage, white clover silage, alfalfa silage, and 50/50 (DM basis) mixtures of grass silage with red clover silage or white clover silage. Concentrates were offered at 4 or $8 \mathrm{~kg} / \mathrm{d}$. 
Similarly, there was little loss of N efficiency when changing from grass silage to a mixture of grass silage and red clover silage in both experiments, suggesting a synergistic effect of the forage mixture on efficiency. Changing to diets based exclusively on red clover silage did not lead to a further increase in milk protein yield. In fact $\mathrm{N}$ efficiency declined markedly suggesting that balancing red clover $\mathrm{N}$ with some other diet component is more important for $\mathrm{N}$ efficiency than the inherent attributes of red clover. The dark coloration of red clover silage reflects the action of polyphenol oxidase to oxidize natural phenols which produce quinones that polymerize with proteins (Jones et al., 1995) and reduce proteolysis (Hatfield and Muck, 1999). However, our studies provide no evidence that this mechanism affected overall $\mathrm{N}$ utilization - though further studies with low protein supplements are required to clarify this question. Relative to $\mathrm{N}$ intake, the efficiency of use of $\mathrm{N}$ from alfalfa silage was low, probably reflecting imbalances between rapidly available $\mathrm{N}$ and indigestible fiber in the rumen and/or the lower energy supply from alfalfa - this is evident from the high digestible N: digestible DM ratio for this diet (Table 7). The inefficient use of $\mathrm{N}$ from alfalfa silage was confirmed by these animals having the highest plasma urea concentrations (Table 11). Broderick et al. (2000) also noted low $\mathrm{N}$ utilization efficiency with alfalfa silage. Further work is needed to design forage mixtures, and protein and energy supplements to optimize $\mathrm{N}$ efficiency with diets based on high levels of legume silages.

\section{CONCLUSIONS}

The techniques of minimal handling and chopping, use of biological inoculants and preparation of legume silages in big bales worked well. We prepared six cuts of each crop, at varying DM contents, over two yr and all materials were well-preserved and aerobically stable.

These studies confirmed the high intake potential and milk production from legume silages. White clover silage consistently led to a $6 \mathrm{~kg} / \mathrm{d}$ increase in milk yield in comparison with grass silage. Whilst white clover is probably not a viable monoculture, owing to low yields, it is clearly beneficial to nutritional value in situations (such as organic farming) that encourage higher levels in swards. The increased intake of legume silages was associated with cows consuming a similar number of larger meals.

There was a general decline in $\mathrm{N}$ use efficiency associated with increasing legume content in the diet, associated with increasing $\mathrm{N}$ intake. Nonetheless, efficiencies for cows offered white clover silage and a mixture of red clover silage and grass silage showed higher $\mathrm{N}$ efficiencies than may have been anticipated, probably be- cause of improved rumen function and/or energy supply to the mammary gland. Clover silages led to a reduction in the content of palmitic acid and an increase in the content of polyunsaturated fatty acids, particularly the $n-3 \alpha$-linolenic acid, in milk.

\section{ACKNOWLEDGMENTS}

The financial support of the EU (project FAIR-CT961832), the Milk Development Council and the Ministry of Agriculture, Fisheries and Food (Department for Environment, Food and Rural Affairs) is gratefully acknowledged. The authors acknowledge the skilled technical assistance of members of the Microbiology, Ruminant Nutrition and Analytical Chemistry laboratories at the Institute.

\section{REFERENCES}

Association of Official Analytical Chemists. 1990. Official Method of Analysis, Vol 1. 15th ed. AOAC. Arlington VA.

Aston, K., W. J. Fisher, A. B. McAllan, M. S. Dhanoa, and R. J. Dewhurst. 1998. Supplementation of grass silage-based diets with small quantities of concentrates : strategies for allocating concentrate crude protein. Anim. Sci. 67:17-26.

Auldist, D.E., K. L. Atkinson, M. J. Silvapulle, D. W. Dellow, and G. H. McDowell. 1999. Utilization of white clover silage fed alone or with maize silage by lactating dairy cows. Austr. J. Exp. Agric. $39: 237-246$

Austin, A.R., K. Aston, H. M. Drane, and N. Saba. 1982. The fertility of heifers consuming red clover silage. Grass For. Sci. 37:101-106.

Bremner, J. M., and D. R. Keeney. 1965. Steam distillation methods for determination of ammonium, nitrate and nitrite. Anal. Chim. Acta. 32:485-495.

Broderick, G. A., R. P. Walgenbach, and E. Sterrenburg. 2000. Performance of lactating dairy cows fed alfalfa or red clover silage as the sole forage. J. Dairy Sci. 83:1543-1551.

Broderick, G. A., R. P. Walgenbach, and S. Maignan. 2001. Production of lactating dairy cows fed alfalfa or red clover silage at equal dry matter or crude protein contents in the diet. J. Dairy Sci. 84:1728-1737.

Castle, M. E., D. Reid, and J. N. Watson. 1983. Silage and milk production: studies with diets containing white clover silage. Grass For. Sci. 38:193-200.

Davis, A. W., and W. B. Hall. 1969. Cyclical change-over designs. Biometrika 56:283-293.

Dewhurst, R. J., and P. J. King. 1998. Effects of extended wilting, shading and chemical additives on the fatty acids in laboratory grass silages. Grass For. Sci. 53:219-224.

Dewhurst, R. J., J. M. Moorby, M. S. Dhanoa, R. T. Evans, and W. J. Fisher. 2000. Effects of altering energy and protein supply to dairy cows during the dry period. 1 . Intake, body condition, and milk production. J. Dairy Sci. 83:1782-1794.

Dewhurst, R. J., R. T. Evans, N. D. Scollan, J. M. Moorby, R. J. Merry, and R. J. Wilkins. 2003. Comparison of Grass and Legume Silages for Milk Production. 2. In vivo and in sacco evaluations of rumen function. J. Dairy Sci. 86:2612-2621.

Fussell, R.J., and D.V. McCalley. 1987. Determination of volatile fatty acids $\left(\mathrm{C}_{2}-\mathrm{C}_{5}\right)$ and lactic acid in silages by gas chromatography. Analyst 112:1213-1216.

Hatfield, R., and R. Muck. 1999. Characterising proteolytic inhibition in red clover silage. Pages 147-148 in Proc. 12th Int. Silage Conf. Uppsala, Sweden.

Hoffman, P. C., D. K. Combs, N. M. Brehm, and D. A. Welch. 1997. Performance of lactating dairy cows fed red clover or alfalfa silage. J. Dairy Sci. 80:3308-3315. 
Hoffman, P. C., D. K. Combs, and M. D. Casler. 1998. Performance of lactating dairy cows fed alfalfa silage or perennial ryegrass silage. J. Dairy Sci. 81:162-168.

Jones, B. A., R. D. Hatfield, and R. E. Muck. 1995. Screening legume forages for soluble phenols, polyphenol oxidase and extract browning. J. Sci. Food Agric. 67:109-112.

Jarvis, S. C., R. J. Wilkins, and B. F. Pain. 1996. Opportunities for reducing the environmental impact of dairy farming managements: a systems approach. Grass For. Sci. 51:21-31.

McAllister, T. A., R. Feniuk, Z. Mir, P. Mir, L. B. Selinger, and K.J. Cheng. 1998. Inoculants for alfalfa silage: Effects on aerobic stability, digestibility and the growth performance of feedlot steers. Livest. Prod. Sci. 53:171-181.

Merry, R. J., M. S. Dhanoa, and M. K. Theodorou. 1995. Use of freshly cultured lactic acid bacteria as silage inoculants. Grass For. Sci. $50: 112-123$.

Ministry of Agriculture, Fisheries and Food. 1986. Analysis of Agricultural Materials. Reference book 427. 3rd ed., London: Her Majesty's Stationery Office.

Moorby, J. M., R. J. Dewhurst, J. K. S. Tweed, M. S. Dhanoa, and N. F. G. Beck. 2000. Effects of altering the energy and protein supply to dairy cows during the dry period. 2. Metabolic and hormonal responses. J. Dairy Sci. 83:1795-1805.

Pahlow, G., C. Rammer, D. Slottner, and M. Tuori. 2002. Ensiling of legumes. Landbauforschung Völkenrode 234:27-30.

Petit, H. V., R. J. Dewhurst, J. G. Proulx, M. Khalid, W. Haresign, and H. Twagiramungu. 2001. Milk production, milk composition, and reproductive function of dairy cows fed different fats. Can. J. Anim. Sci. 81:263-271.

Petit, H. V., R. J. Dewhurst, N. D. Scollan, J. G. Proulx, M. Khalid, W. Haresign, H. Twagiramungu, and G. E. Mann. 2002. Milk production and composition, ovarian function, and prostaglandin secretion of dairy cows fed omega-3 fats. J. Dairy Sci. 85:889-899.

Playne, M. J., and P. McDonald. 1966. The buffering constituents of herbage and of silage. J. Sci. Food Agric. 17:264-268.

Rhodes, I., and F. Ortega. 1997. Forage legumes. Pages 15-27 in Seeds of Progress, British Grassland Society Occ. Symp. 31. ed. J. R. Weddell.

Simopoulos, A. P. 2001. n-3 Fatty acids and human health: defining strategies for public policy. Lipids 36:S83-S89.

Sukhija, P. S, and D. L. Palmquist. 1988. Rapid method for the determination of total fatty acid content and composition of feedstuffs and feces. J. Agric. Food Chem. 36:1202-1206.

Thomas, C., K. Aston, B. G. Gibbs, and J. C. Tayler. 1981. Beef production from silage. 1 . The voluntary intake and live-weight gain of beef cattle given red clover silage. Anim. Prod. 32:143-148.

Thomas, C., K. Aston, and S. R. Daley. 1985. Milk production from silage. 3. A comparison of red clover with grass silage. Anim. Prod. 41:23-31.

Tolkamp, B. J., D. J. Allcroft, E. J. Austin, B. L. Nielsen, and I. Kyriazakis. 1998. Satiety splits feeding behaviour into bouts. J. Theor. Biol. 194:235-250.

Yu, S., J. Derr, T. D. Etherton, and P. M. Kris-Etherton. 1995. Plasma cholesterol-predictive equations demonstrate that stearic acid is neutral and monounsaturated fatty acids are hypocholesterolemic. Am. J. Clin. Nutr. 61:1129-1139. 